\title{
A VEGETABLE EXTRACT USED AS AN ANTIGEN FOR THE KAHN TEST: AN EXPERIMENTAL TRIAL
}

\author{
BY \\ JOHN S. STEVENSON \\ From the Department of Pathology, Stobhill Hospital, Glasgow
}

It has been shown that a substance with properties akin to those of syphilis " antigen " can be extracted from commercial soya bean flour (Stevenson, 1949). The most satisfactory method is the following: 25 g. commercial soya flour is extracted successively with $100,75,75,75 \mathrm{ml}$. pure ether. The flour is then dried and weighed and extracted for one hour at $80^{\circ} \mathrm{C}$. with 95 per cent. ethyl alcohol in the proportion of $5 \mathrm{ml}$. alcohol per $\mathrm{g}$. of flour residue. It will be seen that this process is similar to that used to extract Kahn antigen from dried beef heart, differing only in the alcohol extraction (for one hour at $80^{\circ} \mathrm{C}$. in place of three days at room temperature).

TABLE I

COMPARISON OF TESTS MADE WITH FRESH SOYA EXTRACT

\begin{tabular}{|c|c|c|c|c|}
\hline \multicolumn{2}{|c|}{ Sera } & \multicolumn{3}{|c|}{ Tests } \\
\hline No. & Type & W.R. & Kahn & Kahn S. E. \\
\hline 2 & D & ++ & ++++ & +++ \\
\hline 33 & D & ++ & ++++ & ++ \\
\hline 6 & D & ++ & +++ & + \\
\hline 2 & D & ++ & $+t+$ & - \\
\hline 9 & $\mathbf{T}$ & + & ++ & ++ \\
\hline 2 & $\mathrm{~T}$ & + & ++ & - \\
\hline 14 & $\mathrm{~T}$ & \pm & ++ & + \\
\hline 3 & D & \pm & + & - \\
\hline 2 & D & \pm & - & - \\
\hline 5 & $\mathrm{~T}$ & - & ++ & - \\
\hline 3 & $\mathrm{~T}$ & - & ++ & + \\
\hline 17 & D & - & - & - \\
\hline 2 & D & - & - & $+t$ \\
\hline
\end{tabular}

Kahn S.E. = test incorporating soya extract. $\mathrm{D}=$ " diagnostic" sera.
$\mathrm{T}=$ "treated" sera.
Although the original investigation showed that this extract was a relatively unstable product, it was considered to be of sufficient interest to warrant further experiments. Accordingly, trials were made to estimate the potency of the extract when used as the basis of a standard serological test for syphilis. For this purpose the Kahn test was used. Selected sera of known Wassermann reaction and standard Kahn test readings were tested with a "Kahn" test, incorporating the vegetable extract in place of the usual beef heart antigen; by a comparison of the three readings the properties of the extract were estimated.

\section{Procedure}

The saline titre of freshly-made soya extract was first estimated. This process, carried out as for ordinary Kahn antigen, gave the surprisingly high figure of $1: 2.2$; that is, $2 \cdot 2 \mathrm{ml}$. of 0.85 per cent. $\mathrm{NaCl}$ solution had to be added to $1 \mathrm{ml}$. of the extract to produce a sensitive emulsion. One hundred selected sera were used in the first trial; they were inactivated as usual and tested with the Wassermann reaction (Wyler, 1929 ; 1932), the standard Kahn test, and the "Kahn" test incorporating the soya extract. The results obtained are shown in Table I, where it is seen that the findings of the three tests corresponded fairly closely, but that the degrees of precipitation obtained with the soya extract were much lower than those obtained with the ordinary standard Kahn antigen. Two "diagnostic" sera from cases of clinical syphilis did not react with the soya extract, while six similar sera produced only doubtful reactions. Broadly speaking, therefore, the soya extract was less sensitive than beef heart antigen.

Four weeks after the first trial, the soya extract was again tested, 100 sera being used as before. The results are shown in Table II, where it is seen that the four-week interval had brought about a definite change in the properties of the soya extract. The saline titre remained stationary at $1: 2 \cdot 2$, but the reagent now produced reactions differing widely from the Wassermann reaction and Kahn test findings. Oversensitiveness had developed to such a degree that the results were completely unreliable. Variation of the saline titre did not improve the performance of the extract as an antigen, and it was concluded that the alteration which had occurred in the 
four-week interval only became manifest when the extract was brought into contact with serum and was independent of the saline sensitization. Five sera in the second testing gave negative results with the vegetable extract and it therefore appears that this hypersensitivity is more relative than absolute, as some sera could still produce negative results.

TABLE II

COMPARISON OF TESTS WITH SOYA EXTRACT FOUR WEEKS OLD

\begin{tabular}{c|c|c|c|c}
\hline \multicolumn{2}{c|}{ Sera } & \multicolumn{3}{|c}{ Tests } \\
\hline No. & Type & W.R. & Kahn & Kahn S. E. \\
\hline 17 & D & ++ & ++++ & +++ \\
\hline 7 & D & ++ & ++++ & ++ \\
\hline 19 & D & + & ++ & + \\
\hline 8 & T & \pm & ++ & + \\
\hline 23 & D & - & - & ++ \\
\hline 16 & D & - & - & + \\
\hline 2 & T & \pm & ++ & - \\
\hline 3 & D & - & - & - \\
\hline 5 & T & \pm & - & ++ \\
\hline
\end{tabular}

Kahn S.E. = test incorporating soya extract. $\mathrm{D}=$ = diagnostic" sera.

$\mathrm{T}=$ " treated" sera.

\section{Discussion}

In the past, several workers have experimented with vegetable extracts as antigens in serological tests for syphilis (Heinlein, 1912; Tribondeau, 1913 ; Weiss, 1923), and although in general the results appear to have been satisfactory, confirmatory evidence is lacking and it is suggested that these vegetable antigens produce varying reactions (Eagle, 1937). The findings of the present investigation may shed a little light on the structure of these vegetable antigens if it is accepted that soya flour extracts present, in the main, the features and behaviour of antigens extracted from other members of the vegetable kingdom. It would appear from the results that the soya extract is an even more heterogeneous mixture than ordinary beef heart antigen. In addition to the " reacting substance", which may be considered similar to the active part of beef heart antigen, the existence of two impurities in the soya extract may be postulated :

(a) the factor which produces the high saline titre figure of $1: 2 \cdot 2$;

(b) the factor which, without affecting the saline titre, gives rise to hypersensitivity when the extract is allowed to " age" for a period of four weeks.

It is presumed that the control or elimination of these factors rests with the method of extraction from the soya flour: the present method appears to be at fault in that it does not produce the "antigenic" substance in relatively pure form. Although the newly-made extract is capable of producing about 80 per cent. agreement with Wassermann reaction and standard Kahn readings, the rapidly-developing hypersensitivity makes it unreliable within a short period, i.e. 4 weeks or less. Presumably, then, vegetable material by reason of this hypersensitivity factor is unsuitable as a source of syphilis " antigen".

\section{Summary}

An extract of soya bean flour was substituted for the antigen of the standard Kahn test. When fresh, the extract reacted comparatively strongly with about 80 per cent. of the positive sera tested, but when four weeks old produced unreliable results due to the development of hypersensitivity. It is suggested that these findings indicate the reason why vegetable antigens in general are unsuitable for use in serological tests for syphilis.

I wish to thank Dr. R. D. Stuart, lately City Bacteriologist, Glasgow, for his interest and advice during this experiment.

Eagle, H. (1937). "The Laboratory Diagnosis of Syphilis". H. Kimpton London.

Heinlein, F. (1912). Diss. München. Vergleichende Versuch mit Antigenen verschiedener Herkunst.

Kahn, R. L. (1942). " Serology in Syphilis Control ". The Williams and Wilkins Co., Baltimore.

Stevenson, J. S., (1949). British Journal of Venereal Diseases, $25,78$.

Tribondeau, L. (1913). C. R. Acad. Sci. Paris, 156, 340. Weiss, E. (1923). J. Lab. clin. Med., 8, 476.

Wyler, E. J. (1929).Med. Res. Coun. Spec. Rep. Ser., No. 129 , Lond.

(1932). Ministry of Health, Reports on Public Health and Medical Subjects, No. 67, London. 